\title{
ISU GLOBAL PEREKONOMIAN ISLAM: Telaah Kritis terhadap Tata Kelola dan Aktivitas Lembaga-lembaga Keuangan Islam
}

\author{
Muhdi Kholil \\ (Dosen Ekonomi Syariah STIA Alma Ata Yogyakarta)
}

\begin{abstract}
Indonesia is to be known widely by the world, which has Islamic finance system different from most countries. Indonesia which is in the international forum of financial syriah known "orthodox" or conservative in the application of Islamic principles recognized the economic practice of Islam which is closer to the economic substance of Islam, and relatively completed all aspects of the economy. Islamic economic development not only in the sectors has been developed such as banking, capital markets and non-bank financial institutions other, but also in extended development of the microfinance sector, social and financial practices of real business to meet Islamic principles.

The composition and transaction of Islamic financial products' Indonesia is a fact that is not owned by other countries which are also developing Islamic banking and finance industry. No wonder, since the majority of developing countries in the world of sharia finance industry with the approach of imitation (mimicry) with conventional, and many experts doubt the originality/economic system of Islamic finance, both conventional and expert on Islamic scholars. But on many opportunities, from seminars, conferences and working group forum, many countries are aware that Indonesia has a different form of sharia industry, the application of Islamic finance that has another color.
\end{abstract}

Keyword: Economics, Sharia, Indonesia.

\section{A. Latar Belakang}

Saat ini perkembangan industri keuangan dan perbankan syariah di tanah air menunjukkan pertumbuhan yang sangat pesat. Berdasarkan data akhir tahun 2010 pertumbuhan keuangan syariah nasional secara umum diprakirakan lebih dari 30\%, khusus untuk pertumbuhan perbankan syariah per-September 2011 mampu tumbuh mencapai 48\%. Berdasarkan data yang dikeluarkan oleh Maris Strategies \& The Bankers November 2010, industri keuangan syariah Indonesia berdasarkan besarnya aset peringkatnya naik dari peringkat 17 tahun 2009 menjadi 13 dunia tahun 2010, dimana asetnya bertambah lebih dari dua kali lipat, dari USD 3.3 miliar menjadi 7,2 miliar. Namun begitu, berdasarkan besarnya aset saat ini belum ada satupun perusahaan keuangan syariah Indonesia yang mampu menembus peringkat 25 besar dunia. Dengan karakteristik aplikasi keuangan syariah yang erat dengan aktifitas usaha produktif ekonomi (sektor riil), diyakini bahwa praktek keuangan syariah mampu berkontribusi positif dalam menjaga stabilitas sistem keuangan dan peningkatan daya tahan serta mendorong pertumbuhan ekonomi nasional. Oleh karena itu, diperlukan upaya-upaya yang mampu mengakselerasi pengembangan industri keuangan syariah termasuk perbankan syariah nasional.

Berdasarkan fakta perkembangan ekonomi Islam di atas semakin menimbulkan rasa optimis. Hal ini ditandai dengan semakin banyaknya 
lembaga-lembaga keuangan syariah dan asset yang mereka kelola. Namun, optimisme ini tumbuh berdampingan dengan berbagai kritik yang dialamatkan kepada ekonomi Islam dan lembaga-lembaga ekonomi yang merepresentasikannya. Di antara kritikan itu adalah bahwa lembaga-lembaga keuangan syariah tidak lebih dari lembaga-lembaga kapitalis yang bermerek syariah. Ekonomi Islam dicurigai sebagai ekonomi ekslusif, primordial, dan merupakan wajah religius dari kapitalisme itu sendiri. Berbagai kritik dan kecurigaan itu memang ada benarnya, namun tidak semuanya benar. Produk dan jasa keuangan syariah harus terus dikembangkan agar benar-benar sesuai syariah, tidak saja secara fiqh, tetapi juga secara etika yang melandasinya.

\section{B. Tata kelola (Good Corporate Governance) Lembaga Keuangan Islam}

Perbankan merupakan lembaga keuangan yang menekankan pada prinsip kepercayaan (fiduciary people), maka dalam rangka meningkatkan kepercayaan masyarakat terhadap bank syariah diperlukan adanya pelaksanaan prinsip tata kelola perusahaan yang baik atau yang lebih dikenal dengan prinsip Good Corporate Governance (GCG). Penerapan prinsip GCG pada praktik perbankan syariah menjadi suatu keniscayaan bagi suatu institusi perbankan syariah yang ditujukan kepada adanya tanggung jawab publik ( public accountability) terkait dengan kegiatan operasional bank syariah yang diharapkan benar-benar mematuhi ketentuan-ketentuan syariah. ${ }^{1}$

Dukungan terhadap penerapan GCG pada perbankan syariah juga diberikan oleh Bank Indonesia sebagai pemegang otoritas perbankan dalam negeri dengan segera menyusun kode etik GCG khusus perbankan syariah yang tercantum dalam Peraturan Bank Indonesia No. 11/33/PBI/2009 tentang Pelaksanaan Good Corporate Governance bagi Bank Umum Syariah dan Unit Usaha Syariah pada tanggal 29 Januari 2009 yang kemudian diatur juga dalam Surat Edaran Bank Indonesi No. 12/13/Dpbs tanggal 30 April 2010 perihal pelaksnaan GCG pada Bank Umum Syariah dan Unit Usaha Syariah. Peraturan ini sebenarnya melengkapi tentang pengaturan pelaksanaan tata kelola perusahaan yang baik bagi perbankan syariah berdasarkan UndangUndang No. 21 tahun 2008 tentang Perbankan Syariah. Dalam undangundang tersebut dinyatakan bahwa Bank Syariah dan Unit Usaha Syariah wajib menerapkan tata kelola yang baik yang mencakup prinsip transparansi, akuntabilitas, pertanggungjawaban, profesional dan kewajaran dalam menjalankan kegiatan usahanya. ${ }^{2}$

Awalnya kewajiban penerapan GCG pada perbankan syariah diatur secara bersama dengan pelaksanaan GCG pada perbankan konvensional yang diatur dalam Peraturan Bank Indonesia No. 8/4/PBI/2006 tentang Pelaksanaan Good Corporate Governance bagi Bank Umum. Hal ini disebabkan karena dalam pengoperasiannya, perbankan syariah layaknya perbankan konvensional juga mempunyai kebutuhan untuk menerapkan prinsip-prinsip GCG dikarenakan situasi eksternal dan internal perbankan semakin kompleks juga disertai dengan semakin beragamnya tingkat resiko kegiatan perbankan syariah. Penerapan prinsip GCG selain untuk meningkatkan daya saing perbankan namun juga untuk lebih memberikan perlindungan terhadap masyarakat pengguna jasa perbankan. Penerapan GCG menjadi suatu keniscayaan mengingat sektor perbankan mengelola dana publik. Namun setelah keluarnya PBI No. 11/33/PBI/2009 maka PBI No. 8/4/PBI/2006

${ }^{1}$ Khotibul Umam, Karina Dwi Nugrahati P dan Sekar Ayu, "Implementasi GCG : Upaya Meningkatkan Keparcayaan Pada Bank Syariah", <http://www.ekisonline.com>, diakses terakhir tanggal 20 Desember 2011.

${ }^{2}$ Undang-Undang Perbankan Syariah, Pasal 34 ayat 1.

JURNAL EKONOMI SYARIAH INDONESIA, Volume I, No.2 Desember 2011

Muhdi

Kholil 
beserta ketentuan perubahannya dinyatakan tidak berlaku lagi bagi bank umum syariah dan unit usaha syariah.

Melalui PBI ini juga diatur kegiatan-kegiatan yang menyangkut dengan check and balance yang harus dilakukan bank dan juga untuk menghindari conflict of interest dalam melaksanakan tugas. Untuk meningkatkan kualitas pelaksanaan GCG, bank syariah diwajibkan untuk melakukan self assessment secara komprehensif agar kekurangan bisa segera dideteksi. Nantinya bank akan menyerahkan laporan penerapan GCG ini kepada stakeholders sebagai sebuah bentuk transparansi yang dilakukan oleh manajemen. Pelaksanaan GCG pada perbankan syariah harus berlandaskan pada prinsip keterbukaan (transparancy), akuntabilitas (accontability), pertanggungjawaban (responsibility), profesional (professional) dan kewajaran (fairness).

Selain mengatur tentang GCG secara mendasar, PBI juga mengatur tentang keterkaitan dan tugas serta tanggung jawab oleh Pengawas Shariah Compliance yaitu Dewan Pengawas Syariah. ${ }^{3}$ Dewan Pengawas Syariah berperan penting dalam menjaga syariah compliance yang berkaitan erat dengan pengelolaan perbankan yang berbasis syariah. Hal ini sangat penting ketika perusahaan akan mengeluarkan produk-produk perbankan pada masyarakat. Jadi dalam tata kelola perusahaan yang baik dalam perbankan syariah, maka Dewan Pengawas Syariah yang dijadikan tolak ukur dalam kesuksesan penerapan GCG pada bank syariah tersebut. ${ }^{4}$

Dua hal tersebut merupakan poin terpenting dalam penerapan GCG pada perbankan syariah. Dengan demikian penerapan GCG merupakan sesuatu kebutuhan bagi bank syariah. Penerapan GCG merupakan wujud pertanggungjawaban bank syariah kepada masyarakat bahwa suatu bank syariah dikelola dengan baik, profesional dan hati-hati (prudent) dengan tetap berupaya meningkatkan nilai pemegang saham (shareholder value) tanpa mengabaikan kepentingan stakeholders lainnya. ${ }^{5}$

Implementasi GCG pada perbankan syariah memerlukan adanya pemahaman mengenai prinsip GCG yaitu:

1. Akuntabilitas yang berarti manajemen harus mampu merespon pertanyaan dari stakeholders atas mengenai pertanggungjawaban pelaksanaan manajemen perusahaan.

2. Transparansi yang berarti tersedianya informasi yang akurat, relevan dan mudah dimengerti sehingga stakeholders dapat memberi keputusan.

3. Responsibilitas yaitu perusahaan mampu dikelola sesuai dengan hukum dan peraturan perundang-undangan yang berlaku.

4. Independensi yang berarti tindakan hanya dilakukan untuk kepentingan perusahaan tanpa ada pengaruh dari pihak lain untuk menghindari adanya conflict of interest.

5. Fairness yang berarti adanya perlindungan terhadap hak-hak stakeholders. ${ }^{6}$

\section{Defenisi dan Prinsip Dasar GCG pada Perbankan Syariah}

Komite Cadbury mendefinisikan corporate governance sebagai sistem yang mengarahkan dan mengendalikan perusahaan dengan tujuan, agar mencapai keseimbangan antara kekuatan kewenangan yang diperlukan

Isu

Global
3 Rifka Dejavu, "Penerapan GCG pada Perbankan Syariah", <http://www.rifkadejavucom/.../penerapan-gcg-pada-perbankan-syariah/>, diakses tanggal 20 Desember 2011

${ }^{4}$ Ibid

${ }^{5}$ Ibid

6 Endri,

"Penerapan

Good

Corporate

Governance

pada

Perbankan 
oleh perusahaan untuk menjamin kelangsungan eksistensinya dan pertanggungjawaban kepada stakeholders. Hal ini berkaitan dengan peraturan kewenangan pemilik, direktur, manajer, pemegang saham, dan sebagainya.7Sedangkan OECD mendefinisikan GCG sebagai sekumpulan hubungan antara pihak manajemen perusahaan, board, pemegang saham dan pihak lain yang mempunyai kepentingan dengan perusahaan. Corporate governance juga mensyaratkan adanya struktur perangkat untuk mencapai tujuan dan pengawasan atas kinerja. Corporate governance yang baik dapat memberikan rangsangan bagi board dan manajemen untuk mencapai tujuan yang merupakan kepentingan perusahaan dan pemegang saham harus memfasilitasi pengawasan yang efektif sehingga mendorong perusahaan menggunakan sumber daya dengan lebih efisien. ${ }^{8}$

Menurut Price Waterhouse, corporate governance terkait dengan pengambilan keputusan yang efektif. Dibangun melalui kultur organisasi, nilai-nilai, sistem, berbagai proses, kebijakan-kebijakan dan struktur organisasi, yang bertujuan unruk mencapai bisnis yang menguntungkan, efisien dan efektif dalam mengelola resiko dan bertanggung jawab dengan memperhatikan stakeholders. ${ }^{9}$ Organization A Economic Cooperation and Development mendefinisikan corporate governance sebagai sekumpulan hubungan antara pihak manajemen perusahaan, board dan pemegang saham, dan pihak lain yang mempunyai kepentingan terhadap perusahaan.10 Sedangkan Earnst $\mathcal{E}$ Young mendefinisikan corporate governance terdiri atas sekumpulan mekanisme yang saling berkaitan yang terdiri dari atas pemegang saham institusional, dewan direksi dan komisaris, para manajer yang dibayar berdasarkan kinerjanya, pasar sebagai pengendali perseroan, struktur keuangan, investor terkait dan persaingan produk. ${ }^{11}$

Sedangkan PBI No. 11/33/PBI/2009 tentang Pelaksanaan GCG bagi Bank Umum Syariah dan Unit Usaha Syariah menyebutkan GCG adalah suatu tata kelola bank yang menerapkan prinsip-prinsip keterbukaan (transparency), akuntabilitas (accountability), pertanggungjawaban (responsibility), profesional (professional) dan kewajaran (fairness). ${ }^{12}$ Namun PBI ini menekankan bahwa pelaksanaan GCG pada perbankan syariah harus memenuhi ketentuan prinsip syariah (yang telah ditentukan dalam hukum Islam) yang merupakan ketentuan dasar dalam pengelolaan perbankan yang berbasis syariah.

7 Komite Cadbury (1992). The Business Roundtable, Statemen on Corporate Governance (Washington DC., 1997), hal. 1 dalam Mishardi Wilamarta, "Hak Pemegang Saham Minoritas dalam Rangka Good Corporate Governance", ( Jakarta : Program Pascasarjana, FH UI, cetakan kedua, 2002), hal. 40 dikutip dari Indra Surya \& Ivan Yustiavandana, Penerapan Good Corporate Governance : Mengesampingkan Hak Istimewa Demi Kelangsungan Usaha, (Jakata : Kencana Prenada MediaGrup, 2008), hal 24-25.

${ }^{8}$ Iman Sjahputra Tunggal \& Amin Widjaja Tunggal, " Membangun Good Corporate Governance (GCG)", (Jakarta : Harvarindo, cetakan pertama, 2002), hal.2 dikutip dari Indra Surya \& Ivan Yustiavandana, Penerapan..., hal. 25.

9 Price Waterhouse Coopers, Conceptual Model of Corporate Governance Defenition," (Makalah disampaikan pada BPPN Workshop for Recapitalised, Jakarta, 27 September 2000) dalam Misahardi Wilamarta "Hak Pemegang Saham Minoritas dalam Rangka Good Corporate Governance", (Jakarta : Program Pascasarjana, FH UI, cetakan kedua, 2002), hal. 37 dikutip dari Indra Surya \& Ivan Yustiavandana, Penerapan ..., hal 26.

${ }^{10}$ Forum for Corporate Governance Indonesia, dikutip dari Johannes Ibrahim, " Hukum Organisasi Perusahaan: Pola Kemitraan dan Badan Hukum" (Bandung:Ferika Aditama, 2006), hal. 70.

${ }^{11}$ Hessel Nogi S. Tangkilisan, "Mengelola Kredit Berbasis GCG", (Yogyakarta:Balairung, 2003), hal. 12 dikutip dari Dr. Johannes Ibrahim Hukum Organisasi Perusahaan : Pola Kemitraan \& Badan Hukum, (Bandung : Ferika Aditama, 2006), hal. 69-70.

12 Undang-Undang No. 21 Tahun 2008, Pasal 1 angka 10

JURNAL EKONOMI SYARIAH INDONESIA, Volume I, No.2 Desember 2011

Muhdi

Kholil 
Prinsip dasar pelaksanaan GCG yang diatur dalam PBI dapat dijabarkan sebagai berikut ${ }^{13}$

a. Prinsip keterbukaan

Prinsip ini maksudnya keterbukaan dalam mengemukakan fakta yang materil dan relevan mengenai produk perbankan syariah dan kondisi perbankan itu sendiri serta terbuka dalam proses mengambil keputusan. Jadi pihak pengelola perbankan syariah harus bersikap transparan dengan nasabah melalui jalinan komunikasi yang baik dan berkesinambungan. Di samping itu, para pengelola perbankan syariah harus meletakkan tanggung jawab yang sebesar-besarnya terhadap keselamatan dana yang telah dipercayakan nasabah kepada mereka. Dengan kata lain The corporate governance framework harus memastikan bahwa pengungkapan yang akurat dan tepat waktu memuat seluruh hal yang material atas perusahaan, termasuk kondisi keuangan, kinerja, kepemilikan dan tata kelola atas perusahaan. ${ }^{14}$

b. Prinsip akuntabilitas

Praktek operasional perbankan syariah harus benar-benar dijalankan sesuai prinsip syariah. Dalam hal ini terdapat peran penting Dewan Pengawas Syariah dalam mengawasi operasional perbankan syariah agar tetap berjalan sesuai dengan ketentuan syariah. Dengan semakin meluasnya jaringan perbankan syariah, maka DPS harus lebih meningkatkan perannya secara efektif. Selain itu, para praktisi perbankan syariah wajib mengikuti pengkajian atau training ekonomi syariah secara berkelanjutan. ${ }^{15}$ Karena saat ini masih banyak praktisi bank syariah belum memahami ekonomi syariah dan fiqih muamalah ekonomi. Banyak petinggi perbankan syariah tampaknya tidak begitu peduli akan realitas minimnya pengetahuan kesyariahan para karyawan bank syariah. ${ }^{16}$

c. Prinsip pertanggungjawaban

Prinsip ini lebih menekankan pada kesesuaian pengelolaan bank terhadap peraturan perundang-undangan yang berlaku demi terciptanya sistem pengelolaan perbankan yang sehat. ${ }^{17}$ Prinsip ini juga mengandung arti untuk lebih memperhatikan kepentingan stakeholders perbankan dengan tujuan untuk meningkatkan nilai tambah dari produk dan jasa bagi stakeholders tersebut.

Jadi pengelolaan operasional perbankan syariah hendaknya dapat dipertanggungjawabkan terhadap stekeholders perbankan itu sendiri. Dengan adanya penerapan prinsip ini secara baik maka hal ini akan menjadi nilai tambah bagi perbankan syariah dalam mengembangkan usahanya di masa mendatang.

d. Prinsip profesional

Prinsip ini menekankan agar pengelolaan perbankan syariah sebaiknya dikelola secara profesional ataupun tanpa adnya tekanan atau pengaruh dari pihak lain sehingga conflict of interest dapat dihindari sejauh mungkin. Jadi sikap seluruh jajaran bank sebagai entitas ekonomi yang mandiri, bebas dari kepentingan sepihak

${ }_{13}$ PBI No. 11/33/PBI/2009, Pasal 1 angka (10).

Global

14 Ari Wibowo, "Membangun Perbankan Syariah Menuju Good Corporate Governance"<http:// pesantren.uii.ac.id >, diakses tanggal 20 Desember 2011.

${ }^{15}$ Ari Wibowo, "Membangun Perbankan Syariah....,

${ }^{16} \mathrm{Ibid}$

${ }^{17}$ Khotibul Umam, Karina Dwi Nugrahati P dan Sekar Ayu, “ Implementasi GCG..., 
terutama yang berpotensi merugikan stakeholders dan mampu mengambil keputusan secara obkektif.

e. Prinsip kewajaran

Prinsip ini identik dengan adanya keadilan dan kesetaraan sehingga bank harus senantiasa memperhatikan seluruh kepentingan stakeholders berdasarkan asas kesetaraan dan kewajaran (equal treatment). ${ }^{18}$ Bank harus memberikan kesempatan kepada seluruh stakeholders untuk memberikan masukan dan menyampaikan pendapat bagi kepentingan bank serta mempunyai akses terhadap informasi sesuai dengan prinsip keterbukaan.

\section{Tujuan dan Manfaat Penerapan GCG pada Perbankan Syariah}

Pada dasarnya tujuan penerapan GCG pada perbankan syariah diharapkan dapat meningkatkan nilai tambah bagi stakeholders melalui beberapa tujuan berikut: 19

a. Meningkatkan efisiensi, efektifitas dan kesinambungan suatu organisasi yang memberikan kontribusi kepada terciptanya kesejahteraan pemegang saham, stakeholders lainnya dan merupakan solusi yang elegan dalam menghadapi tantangan perbankan syariah ke depan.

b. Meningkatkan legitimasi perbankan syariah yang dikelola dengan terbuka, adil dan dapat dipertanggungjawabkan

c. Mengakui dan melindungi hak dan kewajiban stakeholders

d. Pendekatan yang terpadu berdasarkan kaidah-kaidah demokrasi, pengelolaan, partisipasi perbankan syariah secara legitimate

e. Meminimalkan agency cost dengan mengendalikan konflik kepentingan yang mungkin timbul antara pihak principal dengan agen

f. Meminimalkan biaya modal dengan memberikan sinyal positif untuk para penyedia modal

g. Meningkatkan nilai perusahaan yang dihasilkan dari biaya modal yang lebih rendah, meningkatkan kinerja keuangan dan persepsi yang lebih baik dari para stakeholders atas kinerja perusahaan di masa depan.

Tujuan GCG diatas menunjukkan isyarat betapa pentingnya hubungan yang baik antara stakeholders yang mempunyai kepentingan dengan industri perbankan sehingga diperlukan tata kelola perusahaan yang baik. GCG dapat dimaknai sebagai rangkaian mekanisme dengan apa suatu perusahaan publik diarahkan dan dikendalikan sesuai dengan harapan para stakeholders. Mekanisme tersebut merefleksikan suatu struktur pengelolaan perusahaan dan menetapkan distribusi hak dan tanggung jawab diantara berbagai partisipan di dalam perusahaan.

Berdasarkan beberapa tujuan $\mathrm{di}$ atas, penerapan GCG pada Perbankan syariah diharapkan dapat memberikan manfaat:20

a. Semakin meningkatnya kepercayaan publik terhadap bank syariah

b. Pertumbuhan industri jasa keuangan syariah dan stabilitas sistem keuangan secara keseluruhan akan senantiasa terpelihara

c. Keberhasilan industri jasa keuangan syariah dalam menerapkan GCG akan menempatkan lembaga keuangan syariah pada level of playing field yang sejajar dengan lembaga keuangan internasional lainnya. 
Tanpa adanya penerapan GCG yang efektif, bank syariah akan sulit untuk bisa memperkuat posisi, memperluas jaringan dan menunjukkan kinerjanya dengan lebih efektif. Kebutuhan bank syariah akan GCG menjadi lebih serius seiring dengan makin kompleksnya masalah yang dihadapi, dimana permasalahan ini akan mengikis kemampuan bank dalam menghadapi tantangan jangka panjang. Dengan demikian, adalah suatu keharusan bagi perbankan syariah untuk memkai semua ukuran yang dapat membantu meningkatkan perannya.

\section{Ruang Lingkup Penerapan GCG pada Perbankan Syariah}

Ruang lingkup penerapan GCG pada perbankan syariah, khususnya Bank Umum Syariah adalah:21

a. Pelaksanaan tugas dan tanggung jawab dewan komisaris dan direksi

b. Kelengkapan dan pelaksanaan tugas dan komite-komite dan fungsi yang menjalankan pengendalian intern Bank Umum Syariah

c. Pelaksanaan tugas dan tanggung jawab Dewan Pengawas Syariah (DPS)

d. Penerapan fungsi kepatuhan, audit intern dan audit ekstern

e. Batas maksimum penyaluran dana

f. Transparansi kondisi keuangan dan non-keuangan Bank Umum Syariah

4. Peran Penting DPS dalam Pemenuhan Prinsip Syariah dalam Pelaksanaan Good Corporate Governance Pada Perbankan Syariah

Peran strategis yang diemban DPS adalah sebagai garda terdepan dalam menjaga kesyariahan sebuah lembaga keuangan yang berlabel syariah. DPS bertanggung jawab untuk memastikan semua produk dan prosedur bank syariah sesuai dengan prinsip syariah. Keberadaan DPS pun dinyatakan secara jelas dalam Undang-Undang No. 21 tahun 2008 tentang Perbankan Syariah dan dalam PBI yang terkait dengan lembaga keuangan syariah. Jadi secara yuridis, DPS di lembaga perbankan syariah menduduki posisi yang kuat karena keberadaannya sangat penting dan strategis.

Untuk melakukan fungsi pengawasan tersebut, anggota DPS harus memiliki kualifikasi keilmuan yang integral, yaitu ilmu fiqih muamalat dan ilmu ekonomi keuangan islam modern, bukan karena kharisma dan kepopulerannya ditengah masyarakat. Jika pengangkatan DPS bukan didasarkan pada keilmuannya, maka fungsi pengawasan DPS tidak akan efektif sehingga dapat menyebabkan terjadinya penyimpangan praktek syariah. 22

Namun peran vital DPS di Indonesia, dalam praktek di lapangan saat ini belum optimal. Ada beberapa faktor utama penyebab peran dan fungsi DPS di Indonesia belum optimal, antara lain; ${ }^{23}$

a. Lemahnya status hukum hasil penilaian kepatuhan syariah oleh DPS akibat ketidakefektivan dan ketidakefisienan mekanisme pengawasan syariah dalam perbankan syariah di Indonesia saat ini

b. Terbatasnya keterampilan sumber daya DPS dalam masalah audit, akuntansi, ekonomi dan hukum bisnis

Isu
${ }^{21}$ PBI No. 11/33/PBI/2009, Pasal 2 ayat (2).

22 Agustianto, "Optimalisasi

DPS Perbankan Syariah", <http://www.scribd.com/.../optimalisasi-dewan-pengawas-syariah-3-agustianto>, diakses tanggal 20 Desember 2011.

${ }^{23}$ Adrian Sutedi, Perbankan Syariah : Tinjauan \& Beberapa Segi hukum, (Bogor : Ghalia Indonesi, 2009), hal. 150.

JURNAL EKONOMI SYARIAH INDONESIA, Volume I, No.2 Desember 2011 
c. Belum adanya mekanisme dan struktur kerja yang efektif dari DPS dalam melaksanakan fungsi pengawasan internal syariah dalam perbankan syariah

Akibat dari ketiga faktor diatas menjadikan peran DPS pada saat ini lebih banyak sebagai penasihat syariah bagi manajemen, alat komunikasi dan marketing bagi bank syariah dan sebagai legislator produk bank syariah. Fungsi pengawasan terhadap proses operasional yang merupakan aktivitas sharia review ex post auditing jarang dilakukan oleh DPS. Salah satu alternatif untuk mengoptimalkan peran DPS dalam bank syariah Di Indonesia adalah dengan mengembangkan fungsi pendukung DPS berupa staf yang memadai untuk membentuk DPS melakukan tugas pengawasan. ${ }^{24}$

Langkah optimalisasi peran dan fungsi DPS dalam pengawasan internal syariah adalah dengan memperbaiki lingkungan eksternal dan internal DPS. Perbaikan lingkungan eksternal DPS menjadi tanggung jawab utama Bank Indonesia sebagai regulator, yaitu menciptakan mekanisme pengawasan syariah yang efektif dan efisien sehingga terbentuk perbankan syariah yang sehat,efisien dan sesuai syariah. Sedangkan tanggung jawab perbaikan lingkungan internal DPS menjadi tanggung jawab DPS dan manajemen bank syariah untuk menciptakan sistem jaminan kepatuhan syariah yang efektif dan efisien untuk mebengun kepercayaan masyarakat terhadap bank syariah. ${ }^{25}$

5. Bentuk Penerapan Aspek Transparansi Kondisi Bank dalam Rangka Pencapaian Good Corporate Governance Pada Perbankan Syariah

Aspek penting dalam pencapaian GCG pada industri perbankan antara lain adalah penerapan transparansi (keterbukaan) terhadap kondisi bank. Prinsip transparansi yang ditandai dengan tersedianya informasi tepat waktu, relevan dan akurat bagi pelaku pasar merupakan salah satu syarat agar disiplin pasar dapat berfungsi secara efektif. Disiplin pasar dapat didefenisikan sebagai aksi stakeholders yang memonitor dan mempengaruhi perusahaan agar meningkatkan kinerja perusahaan. Oleh karenanya, disiplin pasar dipercaya sebagai sarana pengawasan bank yang efektif. ${ }^{26}$

The Based Committee on Banking Supervision Bank for International Settlement atau Bassel Committe menentukan bahwa transparansi merupakan faktor kunci yang berfungsi untuk menjaga efektifitas pengawasan terhadap keamanan, kenyamanan dan reputasi bank. Bassel Committee mendefinisikan transparansi sebagai suatu kegiatan untuk menyampaikan informasi yang dapat dipercaya dan tepat waktu kepada publik, sehingga memungkinkan bagi para pengguna informasi untuk memanfaatkannya sesuai dengan kebutuhan, baik informasi yang terkait dengan kondisi keuangan dan kinerja bank, aktivitas bisnis, profil resiko ataupun praktek manajemen resiko. ${ }^{27}$

Bassel Committee menekankan informasi yang harus disediakan sehingga mampu mencapai level transparansi adalah dengan adanya keakuratan dan kesesuaian informasi yang disajikan yang mencakup 6 (enam) subjek berikut: ${ }^{28}$

${ }^{25}$ Adrian Sutedi, Perbankan Syariah...., hal.150

${ }^{26}$ Zulkarnain Sitompul, Problematika Perbankan, (Bandung:Booksterrace \& Library, cetakan pertama, 2005), hal. 163.

${ }^{27}$ M. Umer Chapra \& Habib Ahmed, Coorporate Governance Lembaga Keuangan Syariah, (Jakarta : P.T Bumi Aksara, 2008) hal. 87

${ }_{28}^{28}$ M. Umer Chapra \& Habib Ahmed, Coorporate Governance...., hal.87-89

JURNAL EKONOMI SYARIAH INDONESIA, Volume I, No.2 Desember 2011

Muhdi

Kholil 
a. Kinerja keuangan

Kinerja keuangan harus mengindikasikan kinerja bank dalam pencapaian profit atau kerugian yang diderita, jumlah pendapatan dan biaya-biaya yang dikeluarkan, kualitas pendapatan dan tern tingkat profitabilitas yang diraih dari tahun ke tahun dan potensinya untuk sewaktu-waktu mendatang (tercermin dalam laporan laba rugi).

b. Posisi keuangan

Posisi keuangan perlu dijelaskan untuk mengevaluasi tingkat permodalan, tingkat solvency, likuiditas dan reputasi bank. Laporan ini juga meliputi informasi tentang karakteristik, jumlah dan kualitas aktiva passiva, komitmen, kontingen liabilities dan dana pemegang saham yang mencerminkan kondisi saat ini dan rata-rata periode yang telah lalu.

c. Strategi manajemen dan kontrol resiko

Hal ini merupakan faktor kunci bagi kinerja dan kondisi bank di waktu mendatang, disamping bagi efektivitas manajemen. Proses disklosur harus meliputi semua resiko yang harus dihadapi oleh bank, baik dari unsur filosofi, kebijakan dan metodologi bagaimana resiko-resiko tersebut akan dihadapi, dikelola, dimonitor dan dikontrol. Selain itu, perlu juga dilakukan upaya untuk memitigasi resiko dengan srana pendukung, misalnya adanya kolateral, perjanjian, komposisi pinjaman, batasan-batasan (batas kredit, batas resiko pasar) dan unsur derivatif.

d. Eksposur resiko

Informasi yang terkait dengan resiko harus disediakan secara kualitatif dan kuantitatif, baik resiko yang inheren dengan aktivitas on balance sheet ataupun off balance sheet yang meliputi resiko kredit, resiko pasar, resiko tingkat suku bunga, resiko valuta asing, resiko likuiditas serta efektivitas strategi yang digunakan untuk mengelola resiko tersebut. Informasi ini akan membantu untuk memenuhi kebutuhan user terhadap kekuatan financial bank dan kemampuan untuk melakukan bisnis secara kontinu dalam waktu yang tak terbatas.

e. Kebijakan akuntansi

Kebijakan ini mencakup prinsip-prinsip dan praktek umum akuntansi, prinsip-prinsip konsolidasi, kebijakan dan metode untuk menjelaskan dan mengenali aset dan kerugian atas hasil usaha, kebijakan untuk menyediakan provisi atas kerugian pinjaman, baik secara umum ataupun secara spesifik, kebijakan tentang penilaian aktiva dan passiva yang tangible dan intangible, sekuritisasi, transakasi valuta asing, pajak penghasilan dan derivatif.

f. Dasar manajemen bisnis dan informasi Corporate governance

Pelaporan informasi harus dilakukan terkait dengan badan hukum usaha (legal entity), dewan direksi (skala, status dan pengalaman anggota), struktur senior manajemen (kualifikasi, pengalaman dan tanggung jawab). Selain itu juga perlu disediakan informasi tentang struktur insentif bank (termasuk remunerasi, bonus kinerja dan stock option), serta aturan main bagi dewan direksi terkait dengan review atas struktur pemberian insentif.

Jadi, pada dasarnya aspek transparansi pada perbankan, termasuk Global juga dalam perbankan syariah merupakan suatu keharusan dan sangat penting agar disiplin pasar dapat berjalan secara efektif. Displin pasar 
akan mampu menjalankan perannya dalam meningkatkan fungsi bank dan menyelamatkan kepentingan pemegang saham manakala semua pihak yang berkepentingan mempunyai akses yang cukup terhadap informasi kegiatan usaha bank, baik yang bersifat kualitatif maupun yang bersifat kuantitatif.

Selain itu, aspek kejujuran (transparansi) ini pada perbankan syariah juga merupakan aspek yang paling penting dalam pencapaian tujuan Good Corporate Governance. Karena dengan adanya prinsip transparansi maka sudah bisa dipastikan bahwa perbankan syariah telah memenuhi kewajiban hukum dan peraturan lainnya yang menggambarkan penilaian masyarakat terhadap reputasi perbankan yang bersangkutan. Dalam persfektif Islam khususnya dalam kerangka operasional perbankan syariah, aspek transparansi merupakan mrupakan factor yang sangat penting untuk member informasi yang tepat dan akurat bagi pihak yang berkepentingan sebagai bagian dari pelaksanaan amanah dan tabligh dalam. ${ }^{29}$

6. Pihak-pihak yang terkait dengan penerapan aspek transparansi pada perbankan syariah

Prinsip transparansi adalah kunci dari efektifnya disiplin pasar yang merupakan penjamin efektifitas terlaksananya GCG pada perbankan syariah dapat berjalan secara berkesinambungan dan maksimal jika didukung oleh beberapapa hal. Salah satunya adalah jika adanya dukungan moral dari para pelaku pasar itu sendiri.

Roopke menyatakan bahwa "disiplin pribadi, keadilan, kejujuran (yang juga berkaitan dengan keterbukaan atau transparansi), kebaikan, semangat kebersamaann peduli kepada masalah kemanusiaan dan etika usaha merupakan hal-hal yang harus dipenuhi oleh seseorang sebelum terjun ke pasar dan berkompetensi antara satu sama lain. Inilah dukungan yang sangat dibutuhkan untu mencegah menurunnya semangat kompetensi dan kejujuran (keterbukaan). ${ }^{30}$

Pihak-pihak yang terkait dengan penerapan aspek transparansi dalam perbankan syariah, diantaranya:

a. Dewan Komisaris

b. Direksi

c. Dewan Pengawas Syariah

d. Pejabat eksekutif dan karyawan bank

e. Akuntan Publik

7. Bentuk-bentuk penerapan aspek transparansi pada kondisi bank dalam rangka pencapaian Good Corporate Governance pada Perbankan Syariah

Ada beberapa bentuk penerapan aspek transparansi pada kondisi bank dalam rangka pencapaian GCG pada Perbankan Syariah, diantaranya:

a. Kondisi keuangan terkait kinerja dan posisi keuangan bank

Kinerja keuangan bank mengindikasikan pencapaian profit maupun kerugian yang diderita bank sedangkan posisi keuangan bank menjelaskan mengenai evaluasi permodalan bank. Bank Indonesia menetapkan bahwa bank harus menyajikan laporan keuangan terkait dalam rangka peningkatan transparansi kondisi keuangan bank.

29 Luqman H2O under, "Penerapan System Syariah Terhadap GLC's pada Sektor Perbankan, <http://www.luqmannomic.wordpress.com/.../penerapan-system-syariah-terhadap-glc's-pada sektor-perbankan/>, diakses tanggal 20 Desember 2011.

${ }^{30}$ M. Umer Chapra \& Habib Ahmed, Coorporate Governance......, hal. 32-33. 
Penyajian laporan keuangan tersebut terdiri atas:

1) Laporan Tahunan

2) Laporan Keuangan Publikasi Triwulanan dan Bulanan

3) Laporan Keuangan Konsolidasi

b. Sistem pengendalian intern

Sistem pengendalian intern sangat diperlukan untuk memastikan pengawasan manajemen dan meningkatkan budaya yang sehat dalam lembaga untuk mengakui dan menilai resiko, mendeteksi permasalahan dalam lembaga serta untuk mengoreksi kelemahan internal. Sistem pengendalian intern perlu dimonitor dengan basis ukuran tertentu untuk memastikan kepatuhan pada aturan dan prosedur, limit pembiayaan, persetujuan dan otorisasi, verifikasi dan rekonsiliasi. Jadi tidak mungkin bisa mengimplementasikan sistem kontrol dengan baik tanpa adanya jalur komunikasi yang efektif dan ketersediaan informasi secara berkala tentang aktivitas bank dan kondisi pasar eksternal yang relevan dalam pengambilan keputusan. Sistem audit internal yang merupakan bagian penting dari kontrol internal harus mempunyai kekuatan dan independensi serta harus dilaporkan secara langsung kepada direksi dan senior manajemen.

c. Strategi manajemen, kontrol dan eksposur resiko

Manajemen resiko adalah serangkaian metodologi dan prosedur yang digunakan untuk mengidentifikasi, mengukur, memantau dan mengendalikan resiko yang timbul dari seluruh kegiatan usaha bank. ${ }^{31}$

Penerapan manajemen resiko pada perbankan syariah paling kurang mencakup; ${ }^{32}$

1) Pengawasan efektif dewan komisaris dan direksi

2) Kecukupan kebijakan, prosedur dan penetapan limit manajemen resiko

3) Kecukupan proses identifikasi, pengukuran, pemantauan, dan pengendalian resiko serta sistem informasi manajemen resiko

4) Sistem pengendalian intern yang menyeluruh

Kebijakan penerapan manajemen resiko setidaknya memuat: ${ }^{33}$

1) Penetapan resiko yang terkait dengan produk dan transaksi perbankan

2) Penetapan penggunaan metode pengukuran dan sistem informasi manajemen resiko

3) Penentuan limit dan penetapan toleransi resiko

4) Penetapan penilaian peringkat resiko

5) Penyusunan rencana darurat (contingency plan) dalam kondisi terburuk (worst case scenario)

6) Penetapan sistem pengendalian intern dalam penerapan manajemen resiko

d. Kebijakan akuntansi

Standar akuntansi yang dikembangkan oleh organisasi bisnis sekuler tidak bisa diaplikasukan secara keseluruhan bagi bank syariah. Untuk itu, Accounting and Auditing Organization for Islamic Financial Institutions (AAOFI) yang didirikan di Bahrain tahun 1991 telah mengembangkan standar bagi bank syariah. Bank syariah

Isu

Global

121

${ }_{31}$ PBI No. 11/25/PBI/ 2009 tentang Perubahan atas PBI No. 5/8/PBI/2003 tentang Penerapan Manajemen Resiko bagi Bank Umum, pasal 1 angka (5).

32 Ibid., pasal 2 angka (2).

${ }_{33}$ PBI No. 5/8/PBI/2003 tentang Manajemen Resiko bagi Bank Umum, Pasal 8.

JURNAL EKONOMI SYARIAH INDONESIA, Volume I, No.2 Desember 2011 
memunyai keharusan untuk mengadopsi standar ini, namun demikian, AAOFI tidak memiliki otoritas atas implementasi standar tersebut. Banyak negara muslim telah bersepakat untuk menerim standar tersebut yang disesuaikan dengan lingkungan masingmasing. ${ }^{34}$

Selain itu, dalam perbankan syariah di Indonesia juga berlaku mengenai ketentuan yang sama tentang Pedoman Akuntansi Perbankan yang berlaku bagi Bank Umum yang menyatakan bahwa bank wajib melakukan pencatatan atas kegiatan usahanya berdasarkan atas Pernyataan Standar Akuntansi Keuangan yang relevan bagi Bank dan Pedoman Akuntansi Perbankan Indonesia. ${ }^{35}$

e. Sistem teknologi Informasi

Perbankan syariah dapat menyempurnakan pelayanan kepada nasabah dengan mengembangkan fitur $e$-banking secara berkelanjutan serta melakukan re-engenering IT environment secara bertahap.

Keseluruhan bentuk penerapan aspek transparansi yang telah dijelaskan diatas merupakan sarana utama pendukung tercapainya GCG pada perbankan syariah. Untuk itu, tujuan dari GCG pada perbankan syariah yakni mewujudkan keadilan bagi stakeholders dengan tetap memenuhi prinsip syariah dapat dicapai dengan adanya penciptaan aspek transparansi yang efektif dalam operasionalisasi industri perbankan syariah.

\section{Aktivitas Lembaga Keuangan Islam}

Selama kurun waktu 30 tahun terakhir pertumbuhan dan perkembangan lembaga keuangan syariah mengalami kemajuan yang sangat pesat, baik di Indonesia maupun di kalangan dunia internasional. Pada awalnya di tahun 1970-an, konsep lembaga keuangan Islam atau yang lebih dikenal dengan sistem syariah hanyalah merupakan diskusi teoritis saja, namun kini hal tersebut telah menjadi realitas faktual yang mencengangkan banyak kalangan. Namun, perkembangan yang mencengangkan ini tidak terlepas dari banyaknya kritikan. Hal ini, sedikit banyak mempengaruhi kepercayaan para pakar akan keberhasilan sistem ekonomi Islam dalam menjawab tantangan kerapuhan sistem ekonomi yang sedang berlangsung. Bahkan kritikan ini mulai memunculkan keraguan terhadap keefektifan ekonomi/keuangan Islam sebagai sistem ekonomi alternatif yang mampu menggantikan sistem ekonomi konvensional. Operasionalnya yang tidak berbeda, struktur produk yang sama, esensi transaksi yang identik, bahkan tidak ada perbedaan mencolok dari prilaku pelaku ekonomi membuat banyak pihak mulai bertanya-tanya, mampukah ekonomi/keuangan Islam bertahan lama. Karena pada akhirnya dengan kecenderungan yang ada saat ini ekonomi/keuangan Islam akan blended (melebur) dalam sistem ekonomi konvensional juga.

\section{Perbankan Syariah}

Maraknya perbankan syari'ah tak lepas dari kritik dan kecaman, yang justru datang dari para ilmuwan Islam sendiri. Mereka berpendapat bahwa bank-bank syari'ah dalam menyelenggarakan transaksi-transaksi perbankan syari'ah justru telah melaksanakannya bertentangan dengan konsepnya. Dengan kata lain, bertentangan dengan semangat dari prinsip-prinsip syari'ah.

${ }^{34}$ Karim R.A., "Islamic Financeand Standardization of Accountingfor Islamic Financial Institutions", (New Horizon:Pp. 5-7, 1990), dikutip dari M. Umer Chapra \& Habib Ahmed, Coorporate Governance.....,hal. 92

35 PBI No. 3/22/PBI/2001, Op. cit., Pasal 30 ayat (1). 
Kritik secara umum, menyoroti lingkungan di mana bank syariah tumbuh dan berkembang, yaitu dalam sistem ekonomi kapitalistik. Karena tumbuh dalam lingkungan kapitalis seperti itulah, banyak terjadi kontradiksi (tanaqudh) antara bank syariah dengan sistem kapitalis yang menjadi tempat hidupnya. Contohnya, dalam bank syariah berlaku prinsip profit and loss sharing dalam akad mudharabah. Sementara dalam sistem kapitalis, khususnya dalam dunia perbankan, tidak dikenal istilah bagi rugi. ${ }^{36}$ Kontradiksi ini, cepat atau lambat akan menimbulkan penyimpanganpenyimpangan. Kondisi ini akan membuat umat Islam hidup dalam kebingungan dan kebimbangan. Karena pilihannya hanya dua: bank konvensional yang menjalankan riba, atau bank syariah yang penuh dengan penyimpangan.

Adapun kritik secara rinci untuk bank syariah, antara lain sebagai berikut :

a. Lemahnya pengawasan manajemen

b. Kurangnya SDM yang cakap untuk mengelola keuangan syariah.

c. Dominannya akad murabahah. ${ }^{37}$

Penerapan usaha-usaha bisnis bank syari'ah, terutama produk murabahah telah menimbulkan masalah moralitas. Dari pengamatan dan penelitian beberapa ilmuwan Islam itu, bank-bank syari'ah, dalam penerapan produkproduknya ternyata bukannya meniadakan bunga dan membagi resiko, tetapi tetap mempertahankan praktek pembebanan bunga dengan menggunakan istilah "label Islam". 38

Menarik untuk mencermati kritik yang dilontarkan oleh Khursi Ahmad mengenai produk Murabahah sebagai berikut: "Murabahah (cost plus financing) and ba'I mu'ajjal (sale with deferred payment) are permitted in the Shariah under certain conditions. Technically, it is not a form of financial mediation but a kind of business participation. The shari'ah assumes that the financier actually buys the goods and then sells them to the client. Unfortunately, the current practice of "buy-back on mark up" is not in keeping with the conditions on which murabahah or ba'I mu'ajjal are permitted. What is being done is a fictitious deal which ensures a predetermined profit to the bank without actually dealing in goods or sharing any real risk. This is againt the letter and spirit of shari'ah injunctions" ${ }^{39}$

Di samping itu, Saeed juga melontarkan kritik terhadap murabahah bahwa justru dari sudut pandang ekonomi, memang tidak ada perbedaan yang mendasar antara mark up dengan bunga. Perbedaan keduanya hanyalah menyangkut soal hukum antara kontrak hutang-piutang dalam bunga dan kontrak jual beli dalam mark up. Pendapat Saeed ini juga diperkuat dengan argumentasi yang dikemukakan oleh Zaidi ${ }^{40}$ sebagai berikut: "In my opinion the cost of credit in bank financing on the basis of murabhah or mark up in price, is the same as in the case of financing on the basis of simple interest, except that in murabahah financing, the price agreed remains the same even if the payment is not made on the due date".

Lebih jauh lagi, Saeed mengemukakan bahwa para teoritisi perbankan syari'ah dari tahun 1940-an sampai akhir 1970-an tidak membayangkan perbankan syari'ah sebagai perbankan berbassis mark up, tetapi mereka

Isu

Global

${ }^{36}$ Ayid Fadhl Asy-Syarawi, Al-Masharif Al-Islamiyah Dirasah Ilmiyah Fighiyah li Al Mumarasat Al-Amaliyah, (Beirut : Ad-Dar al-Jamiiyah, 2007), hal.538

${ }^{37}$ Ayid Fadhl Asy-Syarawi, Al-Masharif Al-Islamiyah...., hal. 510-514

${ }_{38}$ Anita Rahmawaty, Ekonomi Syariah: Tinjauan Kritis Produk Murabahah dalam Perbankan Syariah di Indonesia, Jurnal Ekonomi Islam: La Riba, Vol. I No. 2, Desember 2007, hal. 192

39 Sutan Remy Sjahdeini, Perbankan Islam dan Kedudukannya dalam Tata Hukum Perbankan Indonesia, (Jakarta, Pustaka Utama Grafiti, 1999) hal. 118.

40 Abdullah Saeed, Islamic Banking and Interest, A Study of Prohibition of Riba and its Contemporary Interpretation, Leiden: E.J. Brill,1996) hal. 93

JURNAL EKONOMI SYARIAH INDONESIA, Volume I, No.2 Desember 2011 
mengandaikan perbankan syari'ah sebagai perbankan berbasis profit and loss sharing dengan menggunakan konsep musyarakah dan mudharabah. Siddiqi dalam karyanya Banking without Interest tidak menyinggung murabahah sama sekali, demikian pula halnya dengan Interest-Free Banking karya Uzair. Bahkan dengan tegas, Siddiqi sebagaimana dikutip oleh Saeed ${ }^{41}$ menyatakan pendapatnya untuk menghapus instrumen murabahah dari perbankan syari'ah.

Beberapa kritik terhadap praktek murabahah di perbankan syari'ah juga dikemukakan oleh beberapa ulama, diantaranya adalah:42

1. Murabahah ini bukan jual beli melainkan hilah dengan tujuan mengambil riba.

2. Murabahah merupakan jual beli 'inah yang diharamkan Islam.

3. Murabahah merupakan ba'I atani fi ba'iah.

4. Murabahah merupakan bai' al-ma'dum.

Meskipun banyak kritik yang diarahkan kepada praktek murabahah di perbankan syari'ah, namun hal ini justru mengindikasikan bahwa sebenarnya produk murabahah ini direspon secara luas. Oleh karena itu, dalam perjalanannya para teoritisi dan praktisi perbankan syari'ah masih terus melakukan kajian dan mengkritisi secara serius mekanisme kontrak murabahah yang sesuai dengan semangat dari prinsip-prinsip syari'ah dalam rangka mencapai tujuan pembumian ekonomi syari'ah di Indonesia.

\section{Asuransi Syariah}

Tampaknya semua mekanisme takaful Islam telah berjalan sesuai syariah, tetapi banyak pertanyaan atas kesyariahannya. Pertanyaan tersebut berpangkal pada dua perkara yakni: 1) Tentang terpenuhi tidaknya syarat bagi sahnya aqad jaminan serta terpenuhi tidaknya syarat dalam aqad jaminan yang disahkan syara', dan 2) Seputar kedudukan perusahaan takaful itu sendiri: apakah ia berperan sebagai perusahaan penjamin, ataukah sebagai perusahaan pengelola dana nasabah (mudharib), atau hanya sekedar sebagai pialang (broker) yang mempertemukan nasabah sebagai pemilik dana dengan pengusaha.

Menurut fiqh Islam, terdapat lima rukun dhaman, yakni adanya pihak yang menjamin (dhamin), yang dijamin (madhmun 'anhu) dan yang menerima jaminan (madhmun lahu), dan adanya barang atau beban (harta) yang harus ditunaikan, yakni berupa hak harta yang wajib dibayar atau akan jatuh tempo pemenuhannya, serta adanya ikrar atau ijab qabul. ${ }^{43}$ Apakah kelima rukun ini sudah ada dalam asuransi takaful?

Pada sisi lain ada kesamaran dalam mekanisme asuransi takaful. Bila dikaji lebih jauh, di dalam mekanisme kerja asuransi takaful agaknya berlansung dua aqad sekaligus, yakni aqad saling menanggung di antara para nasabah (aqad takafuli) dan aqad syirkah antara nasabah dan perusahaan takaful yang dibuktikan dengan adanya bagi hasil uang nasabah yang disimpan perusahaan asusransi takaful. Dalam hal aqad saling menanggung, siapakah yang menjadi penanggung dan yang ditanggung? Bila aqad dalam Takaful adalah aqad takafuli antar peserta, pernahkah aqad itu berlangsung sebagaimana mestinya diantara merka sendiri ? Bila diantara nasabah sudah

41 Abdullah Saeed, Islamic Banking and Interest...., hal. 95

42 Perdebatan pendapat ulama mengenai status keabsahan praktek murabahah di perbankan syari'ah ini dapat dibaca lebih detail dalam Yusuf Qardhawi, Bai' al-Murabahah li al-Aamir bi asy-Syira' Kama Tajriyah al-Masharif al-Ilmiyah,( t.tp: Maktabah Wahbah, 1987), hal. 26.

43http:/ / corpusalienum.multiply.com/journal/item/683/Menyoal_Asuransi_Konvensional_ dan_Asuransi_Takaful?\&show_interstitial=1\&u=\%2Fjournal\%2Fitem, diakses terakhir pada tanggal 20 Desember 2011

JURNAL EKONOMI SYARIAH INDONESIA, Volume I, No.2 Desember 2011

Muhdi

Kholil 
bisa saling menanggung, lalu apa fungsi perusahaan asuransiTakaful ? Maksudnya, dalam hal ini kedudukan perusahaan Takaful sebagai apa? Apakah sebagai pihak pengelola dana nasabah? Bila sebagai pengelola dana nasabah, mengapa disebut perusahaan Takaful, mengapa bukan perusahaan biasa sebagaimana yang lain?

Tetapi, benarkah perusahaan asuransi Takaful bertindak sebagai pengelola dana nasabah ? Ternyata tidak, karena dana yang dikumpulkan tidak dikelola sendiri (menurut UU yang berlaku Takaful termasuk lembaga keuangan non bank yang hanya boleh menghimpun dana tetapi tidak boleh menyalurkan apalagi memutarnya sendiri) melainkan disalurkan ke BMI. Karena bukan sebagai lembaga pengelola, maka semestinya perusahaan Takaful hanya berfungsi sebagai pialang (perantara) antara nasabah dan pengusaha (yang dalam faktanya itupun tidak pernah ada), ataupun wakil nasabah dalam berhadapan dengan pengusaha. Sebagai perantara, Takaful berhak mendapat komisi. Sedang sebagai wakil, Takaful bisa mendapat imbalan (ujrah atau 'iwad). Akan tetapi, dalam kenyataanya mengapa perusahaan memungut bagi hasil, dan karenanya juga menanggung kerugian?.

Alternatif penyelesaiannya adalah sebagai berikut: Akad saling menanggung bisa dilakukan diantara para peserta. Jadi sejumlah para nasabah membentuk kesepakatan bersama untuk saling menanggung dengan cara mengumpulkan sejumlah uang. Bisa pula disepakati dana yang dikumpulkan dipakai sebagai modal usaha yang diputar oleh sebuah perusahaan, dimana sebagian atau seluruh keuntungan itulah yang digunakan sebagai dana tanggungan. Bila berlebih, bisa disepakati lebih jauh untuk menanggung orang lain yang bukan anggota takaful. "Perusahaan Takaful" (bisa dicari nama lain yang lebih netral) dalam hal ini bisa berperan sebagai wakil kedua belah pihak (pengusaha dan para nasabah), yang mengurusi segala hal yang berkaitan dengan kegiatan takaful. Lembaga ini memperoleh dana bisa dari pungutan biaya administrasi dari para nasabah atau imbalan baik dari nasabah ataupun pengusaha. Dana tersebut lebih banyak digunakan untuk biaya operasional atau mengembangkan kegiatan takaful bukan untuk mencari keuntungan. Dengan demikian lembaga itu didirikan memang untuk kegiatan nirlaba, yang berbeda sama sekali baik dari falsafah pendirian, tujuan, maupun tata kerjanya dengan perusahaan asuransi dalam sistem kapitalis-individualistik. ${ }^{44}$

Asuransi syariah di Indonesia pada umumnya dipandang masih bersifat non syariah yang bertentangan dengan ajaran Islam. Hal tersebut menimbulkan masalah mengenai halal dan haramnya asuransi tersebut dari sudut pandang hukum Islam. Kelemahan-kelemahan asuransi syariah saat ini tampak dari:

a. Akad penundukan

Kelemahan dari asuransi syariah saat ini adalah masih terdapat akad $i d z^{\prime} a n$. Maksudnya adalah akad yang merupakan penundukan pihak yang kuat kepada pihak yang lemah. Pihak yang kuat lebih dominan terletak pada perusahaan yang menentukan syarat-syarat yang tidak dimiliki tertanggung. Syarat-syarat yang dibuat oleh perusahaan asuransi syariah telah dibakukan pada akadnya atau perjanjiannya. Perjanjian yang telah dibakukan tersebut menimbulkan posisi perusahaan asuransi syariah menjadi lebih kuat dibandingkan dengan nasabah pesertanya. Hal tersebut

Isu

Global

${ }^{44}$ http://corpusalienum.multiply.com/journal/item/683/Menyoal_Asuransi_Konvensional_ dan_Asuransi_Takaful?\&show_interstitial $=1 \& u=\% 2 F j o u r n a l \% 2 F i t e m$, diakses terakhir pada tanggal 20 
menyebabkan pertentangan dengan prinsip keadilan yang sesuai dengan syariat Islam. ${ }^{45}$

b. Mengandung unsur pemerasan

Ketika nasabah atau para pemegang polis tidak bisa melanjutkan pembayaran preminya, seringkali uang premi yang sudah dibayar jadi hangus atau hilang dan pihak asuransi juga tidak memberikan surat pemberitahuan mengenai hal tersebut. Seharusnya premi yang sudah diberikan oleh peserta dikembalikan sesuai dengan kesepakatan bagi hasil pada awal perjanjian. ${ }^{46}$

c. Mengandung unsur penipuan

Dalam klausul perjanjian yang dibuat oleh pihak asuransi syariah biasanya masih ada yang kurang ditonjolkan saat penawaran. Demikian juga dengan resiko-resiko buruk yang akan terjadi, dan umumnya disembunyikan oleh pihak asuransi syariah. Terdapat beberapa peserta yang kemudian jera berurusan dengan perusahaan asuransi syariah yang cenderung tidak pernah mau berkompromi. ${ }^{47}$

d. Diinvestasikan pada Lembaga Ribawi

Perusahaan asuransi masih menginvestasikan dana peserta kepada pihak lain atau lembaga yang menjalankan bisnis dengan praktik ribawi, dimana lembaga tersebut menggunakan sistem bunga dalam pendapatannya. Bunga inilah yang diperoleh oleh perusahaan asuransi syariah dan sebagiannya menjadi uang yang akan diterima atau dibayarkan kepada peserta asuransi bila ada yang melakukan klaim kepada mereka.

\section{BMT}

BMT (Baitul Maal Wa Tamwil) merupakan salah satu model lembaga keuangan syariah paling sederhana yang saat ini banyak muncul dan tenggelam di Indonesia. Keberadaan BMT dengan jumlah yang signifikan pada beberapa daerah di Indonesia tidak didukung oleh faktor-faktor pendukung yang memungkinkan BMT untuk terus berkembang dan berjalan dengan baik. Fakta yang ada di lapangan menunjukkan banyak BMT yang tenggelam dan bubar. Masyarakat dalam menilai Lembaga Keuangan Syari'ah khususnya BMT ada yang bersikap sinis. Bahwa praktek BMT tidak beda dengan praktek Bank Konvensional, mereka beranggapan bahwa BMT dalam mengambil keuntungan lebih besar dari bunga Bank Konvensional, di Bank Konvensional mengambil bunga 1\% hingga 2\% setiap bulan sedangkan di BMT dalam mengambil keuntungan lebih dari $2 \%$.

Ada dugaan adanya praktek-praktek pengelolaan dana yang belum sepenuhnya bernuansa syari'ah, terjadi banyak deviasi antara teori dan praktek dalam operasional sebagian besar BMT, terutama yang berhubungan dengan penerapan prinsip-prinsip syari'ah dalam akad pengerahan dana dan penyaluran dana kepada masyarakat.Masalah-masalah tersebut disebabkan karena prinsip-prinsip syari'ah yang menjadi dasar rujukan dalam operasional BMT belum sepenuhnya dipahami dengan baik oleh sebagian besar pengelola BMT sendiri, inilah yang melahirkan banyak penyimpangan

45 DewiGemala, Aspek-Aspek Hukum dalam Perbankan dan Perasuransian Syariah di Indonesia, Edisi Revisi, (Jakarta: Kencana Prenada Media Group, 2006), hal. 135

46 Akad Takafuli dan Tabarru Dalam Asuransi Syariah", http://www.pojokasuransi.com, diakses terakhir tanggal 20 Desember 2011

H7 Hermawan Kartajaya, "Ekonomi Islam Itu Adil dan Indah",http:/ / www.pojokasuransi.com/forum, diakses terakhir tanggal 20 Desember 2011 
dalam praktek pengelolaan lembaga mikro keuangan syari'ah yang sering mengundang kritik. 48

Dengan melihat fenomena di atas perkembangan BMT dipandang belum sepenuhnya mampu menjawab problem real ekonomi yang ada di kalangan masyarakat. Hal ini disebabkan oleh faktor internal dan eksternal, yaitu:

\section{a. Faktor Internal}

1) Permodalan dan Sumber Pendanaan

BMT umumnya memiliki modal yang relatif kecil dan sulit untuk menambah modal apabila diperlukan. Menurut riset yang dilakukan oleh Junaidi, pada umumnya BMT yang ada di lapangan memiliki aset berkisar Rp. 10-30 juta atau sebesar 51\%-nya berada pada katagori Rp 1030 juta-an. Ada beberapa BMT yang memiliki aset di atas Rp 100 juta tetapi jumlahnya hanya $5 \%{ }^{49}$ Modal pendanaan merupakan fondasi dalam oprasional suatu lembaga keuangan. Hal ini berarti ketersediaan dana yang terbatas pada sebagian besar BMT di Indonesia akan mempersulit pengembangan usahanya. Sehingga akumulasi kebutuhan dana masyarakat belum bisa dipenuhi oleh BMT. Hal ini yang menjadikan nilai pembiayaan dan jangka waktu pembayaran kewajiban dari nasabah cukup cepat dan belum tentu pembiayaaan yang diberikan BMT cukup memadai untuk modal usaha masyarakat. Dalam melayani penyaluran dana kepada masyarakat dinilai belum maksimal karena masih banyak masyarakat yang berhubungan dengan rentenir walaupun keberadaan BMT cukup dikenal. Hal ini disebabkan masyarakat membutuhkan pemenuhan dana yang memadai dan pelayanan yang cepat, walaupun ia membayar bunga yang cukup tinggi.

2) Sumber Daya Manusia (SDM)

BMT rata-rata memiliki SDM yang produktifitasnya rendah karena tingkat pendidikan yang rendah, tidak adanya standar dalam sistem rekruitmen, jenjang karir yang tidak jelas, sistem penggajian dan bonus yang tidak memadai, dan kurangnya upaya peningkatan kemampuan melalui kegiatan pelatihan dan pendidikan yang menyebabkan pengelola BMT kurang profesional dalam bekerja.

Para pengelola BMT dalam menjalankan tugasnya masih banyak yang mengutamaan kepentingan pribadi dan mengabaikan rasa dedikasi demi memajukan eksistensi BMT, bahkan praktek-praktek KKN juga masih dilakukan oleh beberapa pengelola BMT di Indonesia. Hal-hal tersebut menyebabkan kualitas SDM tidak memadai dan tidak mampu bersaing dengan lembaga keuangan lainnya yang mengakibatkan proses perjalanannya, berjalan tidak sesuai dengan harapan.

3) Inovasi di Bidang Pemasaran

Sebagian besar BMT tidak mampu mengembangkan produk-produk baru yang inovatif yang mampu meningkatkan daya saing dengan lembaga keuangan berskala besar dan dengan lembaga keuangan mikro lainnya. Hal ini dikarenakan umumnya BMT memiliki kualitas SDM yang rendah, dana yang terbatas untuk membiayai kegiatan riset dan pengembangan pasar, serta tidak memiliki strategi untuk mengatasi hambatan tersebut. Pengetahuan pengelola BMT juga dinilai sangat terbatas dalam menangkap dan menyikapi masalah ekonomi yang terjadi di tengah masyarakat. Sehingga menyebabkan dinamisasi dan inovasi BMT tersebut kurang. 
4) Teknologi Informasi

Terdapat banyak BMT yang belum memiliki perangkat teknologi informasi untuk mendukung kegiatan operasionalnya ataupun jika ada tidak mampu memanfaatkannya secara optimal karena keterbatasan SDM. Hal ini menyebabkan BMT tidak memiliki kemampuan akses terhadap informasi baik yang berasal dari intern lembaga maupun ekstern sehingga tidak mampu menyediakan informasi yang cepat, lengakap dan akurat khususnya dalam proses penyusunan perencanaan maupun pengambilan keputusan.

\section{b. Faktor Eksternal}

1) Persaingan

Persaingan yang dihadapi berasal dari sesama BMT, lembaga keuangan mikro lainnya maupun dengan bank umum yang memiliki unit usaha kecil atau cabang di daerah pedesaan. BMT cenderung menganggap BMT lain sebagai lawan yang harus dikalahkan yang mengakibatkan kebersamaan dalam menjalin koordinasi demi kelancaran operasionalisasi menjadi terhambat. Ini merupakan salah satu faktor yang menghambat kemajuan BMT di Indonesia pada umumnya.

2) Tingkat Kepercayaan Masyarakat

Tidak dapat di pungkiri, ada beberapa kelemahan dan penyakit yang kini dirasakan oleh BMT, umumnya berkisar pada lemahnya sumber daya manusia, manajemen, fasilitas, servis, permodalan, dan lain sebagainya. Kelemahan-kelemahan BMT tersebut, pada gilirannya berujung pada sulitnya menumbuhkan kepercayaan masyarakat luas (public trust) terhadap jasa dan pelayanan yang bisa diberikan BMT.

Apalagi ada beberapa kalangan yang memandang sinis terhadap maraknya perkembangan dan pertumbuhan lembaga keungan syariah, bahkan kalangan umat Islam sendiri. Sinisme terhadap lembaga keuangan Islam tersebut dapat dilihat dari kepercayaan masyarakat Islam terhadap Bank Syariah sangat rendah. Hal tersebut dapat dilihat dari partisipasi umat Islam dalam investasi atau perguliran modal. Bahkan beberapa ilmuwan muslim ada yang mengecam perbankan syariah, mereka berpendapat bahwa bank-bank Islam dalam menyelenggarakan transaksi-transaksinya justru bertentangan dengan konsepnya. Dengan kata lain, bertentangan dengan semangat syariah. Mereka meragukan mengenai kegiatan-kegiatan usaha-usaha bank-bank Islam tersebut, yang notabene bermaksud untuk menghindarkan pemungutan bunga dan bermaksud agar risiko dipikul bersama, dalam pelaksanaannya sudah diaplikasikan sesuai dengan tujuan tersebut atau hanya penggantian istilah belaka. ${ }^{50}$

3) Jaringan

Tidak ada jaringan yang kuat merupakan suatu kelemahan besar yang dihadapi BMT. Lemahnya jaringan berarti bahwa jaringan ada namun tidak memberikan arti dan perubahan yang lebih baik kepada anggota-anggota jaringan tersebut. Sistem jaringan yang lemah juga menyulitkan dalam menghadapi suatu permasalahan. Hal ini disebabkan beberapa BMT cenderung menghadapi masalah yang sama, misalnya nasabah yang bermasalah. Kadang ada satu nasabah yang tidak hanya bermasalah disatu BMT tetapi di BMT lain juga bermasalah. Apabila terdapat jaringan koordinasi yang baik antar BMT maka nasabah tersebut tidak akan dapat mengakses dana dari BMT lainnya karena dia sudah

${ }^{50}$ http://www.gema-pkm.org/, diakses terakhir pada tanggal 20 Desember 2011

Muhdi

Kholil

JURNAL EKONOMI SYARIAH INDONESIA, Volume I, No.2 Desember 2011 
bermasalah di salah satu BMT. Akan tetapi kenyataan di lapangan menunjukkan bahwa jaringan koordinasi antar BMT masih lemah dan ampai saat ini belum ada suatu lembaga khusus yang menjadi induk BMT di seluruh Indonesia. Sehingga BMT cenderung berdiri sendirisendiri serta mengalami kesulitan dalam mengembangkan usahanya.

4) Kebijakan Pemerintah

BMT yang berkembang di Indonesia tidak didukung dengan ketentuan hukum dan sistem pengawasan atau pembinaan yang memadai. Saat ini BMT menggunakan RUU Badan Hukum Koperasi dinilai kurang sesuai denagan kondisi BMT yang merupakan jenis lembaga intermediasi berskala mikro. Namun BMT juga bukan perbankan sehingga otoritas pengawasan tidak berada di Bank Indonesia. Hal ini menyebabkan kedudukan BMT sebagai lembaga keuangan secara hukum belum jelas sehingga ada sebagian masyarakat yang mengasumsikannya sebagai bank gelap.

5) Pengawasan dan Pembinaan

Belum adanya standar pembinaan dan pengawasan yang baku untuk BMT dan ada beberapa BMT yang belum mempunyai lembaga pengawas, secara tidak langsung telah ikut menghambat perkembangan BMT. Pengawasan yang efektif merupakan alat kontrol bagi BMT untuk beroperasi secara sehat sehingga dapat berkembang secara wajar dan sehat serta memperoleh kepercayaan masyrakat.

\section{Kesimpulan}

Ditengah kritikan-kritikan praktek lembaga keuangan syariah seperti di atas dan masih dalam usaha mewujudkan Good Cooperate Governance, Indonesia secara perlahan mulai dikenal luas oleh dunia, memiliki aplikasi ekonomi/keuangan syariah yang berbeda dengan negara-negara kebanyakan. Indonesia yang dalam forum internasional keuangan syriah dikenal "ortodok" atau konservatif dalam penerapan prinsip-prinsip syariah, kini dikenali memiliki praktek ekonomi Islam yang lebih mendekati substansi ekonomi Islam (jika sulit juga diklaim lebih syariah) serta relatif komplit pada semua aspek ekonomi. Perkembangan ekonomi syariah bukan hanya di sektor yang memang telah banyak dikembangkan seperti perbankan, pasar modal dan lembaga keuangan non-bank lainnya, tetapi perkembangannya merambah pada sektor keuangan mikro, keuangan sosial dan praktek-praktek usaha riil yang mencoba memenuhi prinsip-prinsip syariah.

Komposisi dan mekanisme transaksi dari produk-produk keuangan syariah yang dimiliki Indonesia ini sebuah fakta yang tidak dimiliki negaranegara lain yang juga mengembangkan industri perbankan dan keuangan syariah. Tidak heran, karena mayoritas negara di dunia mengembangkan industri keuangan syariahnya dengan pendekatan peniruan (mimicry) dengan konvensional, maka banyak pakar yang meragukan orisinalitas sistem ekonomi/keuangan Islam, baik pakar konvensional maupun pakar syariah. namun pada beberapa kesempatan, baik seminar, konferensi dan forum kelompok kerja, banyak negara yang kini menyadari bahwa Indonesia memiliki bentuk industri syariah yang berbeda, aplikasi ekonomi syariah yang memiliki warna lain.

Isu

Global 


\section{DAFTAR PUSTAKA}

Asy-Syarawi, Ayid Fadhl, Al-Masharif Al-Islamiyah Dirasah Ilmiyah Fiqhiyah li Al Mumarasat Al-Amaliyah, Beirut: Ad-Dar al-Jamiiyah, 2007

Chapra, M. Umer \& Habib Ahmed, Coorporate Governance Lembaga Keuangan Syariah, Jakarta : P.T Bumi Aksara, 2008

Coopers, Price Waterhouse, Conceptual Model of Corporate Governance Defenition, Makalah disampaikan pada BPPN Workshop for Recapitalised, Jakarta, 27 September 2000

Gemala, Dewi, Aspek-Aspek Hukum dalam Perbankan dan Perasuransian Syariah di Indonesia, Edisi Revisi, Jakarta: Kencana Prenada Media Group, 2006

Ibrahim, Johannes, Hukum Organisasi Perusahaan: Pola Kemitraan dan Badan Hukum, Bandung: Ferika Aditama, 2006

Ilmi, Makhalul, Teori dan Praktek Lembaga Mikro Keuangan Syari'ah, Yogyakarta : UII Press, 2002

Karim, R.A., Islamic Financeand Standardization of Accountingfor Islamic Financial Institutions, New Horizon: Pp. 5-7, 1990

Komite Cadbury, The Business Roundtable, Statemen on Corporate Governance, Washington DC, 1997

Qardhawi, Yusuf, Bai' al-Murabahah li al-Aamir bi asy-Syira' Kama Tajriyah alMasharif al-Ilmiyah, t.tp: Maktabah Wahbah, 1987

Rahmawaty, Anita Ekonomi Syariah: Tinjauan Kritis Produk Murabahah dalam Perbankan Syariah di Indonesia, Jurnal Ekonomi Islam: La Riba, Vol. I No. 2, Desember 2007

Saeed, Abdullah, Islamic Banking and Interest, A Study of Prohibition of Riba and its Contemporary Interpretation, Leiden: E.J. Brill,1996

Sitompul, Zulkarnain, Problematika Perbankan, Bandung: Booksterrace \& Library, 2005

Sjahdeini, Sutan Remy, Perbankan Islam dan Kedudukannya dalam Tata Hukum Perbankan Indonesia, Jakarta, Pustaka Utama Grafiti, 1999

Sutedi, Adrian, Perbankan Syariah : Tinjauan \& Beberapa Segi hukum, Bogor : Ghalia Indonesia, 2009

Tangkilisan, Hessel Nogi S, Mengelola Kredit Berbasis GCG, Yogyakarta:Balairung, 2003

Tunggal, Iman Sjahputra Tunggal \& Amin Widjaja, Membangun Good Corporate Governance (GCG), Jakarta: Harvarindo, 2002

Wilamarta, Mishardi, Hak Pemegang Saham Minoritas dalam Rangka Good Corporate Governance", Jakarta: Program Pascasarjana, FH UI, 2002

Yustiavandana Indra Surya \& Ivan, Penerapan Good Corporate Governance : Mengesampingkan Hak Istimewa Demi Kelangsungan Usaha, Jakata : Kencana Prenada MediaGrup, 2008

Agustianto, "Optimalisasi DPS Perbankan Syariah", <http://www.scribd.com/.../optimalisasi-dewan-pengawas-syariah3-agustianto>, diakses tanggal 20 Desember 2011.

Ari Wibowo, "Membangun Perbankan Syariah Menuju Good Corporate Governance" <http:// pesantren.uii.ac.id>, diakses tanggal 20 Desember 2011.

Endri, "Penerapan Good Corporate Governance pada Perbankan Syariah",<http://www.tazkiaonline.com.mht>, diakses tanggal 20 Desember 2011.

Hermawan Kartajaya, "Ekonomi Islam Itu Adil dan Indah",http://www.pojokasuransi.com/forum, diakses terakhir tanggal 20 Desember 2011 
Khotibul Umam, Karina Dwi Nugrahati P dan Sekar Ayu, "Implementasi GCG : Upaya Meningkatkan Keparcayaan Pada Bank Syariah", $<$ http://www.ekisonline.com>, diakses terakhir tanggal 20 Desember 2011.

Luqman H2O under, "Penerapan System Syariah Terhadap GLC's pada Sektor Perbankan,

<http://www.luqmannomic.wordpress.com/.../penerapan-systemsyariah-terhadap-glc's-pada sektor-perbankan/>, diakses tanggal 20 Desember 2011.

Rifka Dejavu, "Penerapan GCG pada Perbankan Syariah", <http://www.rifkadejavucom/.../penerapan-gcg-pada-perbankan-syariah/>, diakses tanggal 20 Desember 2011.

http://corpusalienum.multiply.com/journal/item/683/Menyoal_Asuransi_Konv ensional_dan_Asuransi_Takaful?\&show_interstitial=1\&u=\%2Fjournal \%2Fitem, diakses terakhir pada tanggal 20 Desember 2011

http:/ / www.pojokasuransi.com, Akad Takafuli dan Tabarru Dalam Asuransi Syariah, diakses terakhir tanggal 20 Desember 2011

http://www.bmtlink.web.id/, diakses terakhir pada tanggal 20 Desember 2011

http://www.gema-pkm.org/, diakses terakhir pada tanggal 20 Desember 2011

Undang-Undang No. 21 Tahun 2008, Pasal 1 angka 10.

Undang-Undang Perbankan Syariah, Pasal 34 ayat 1.

PBI No. 11/33/PBI/2009, Pasal 1 angka (10).

PBI No. 11/25/PBI/2009 tentang Perubahan atas PBI No. 5/8/PBI/2003 tentang Penerapan Manajemen Resiko bagi Bank Umum, pasal 1 angka (5).

PBI No. 5/8/PBI/2003 tentang Manajemen Resiko bagi Bank Umum, Pasal 8.

PBI No. 3/22/PBI/2001, Pasal 30 ayat (1).

PBI No. 11/33/PBI/2009, Pasal 2 ayat (2).

Isu

Global 